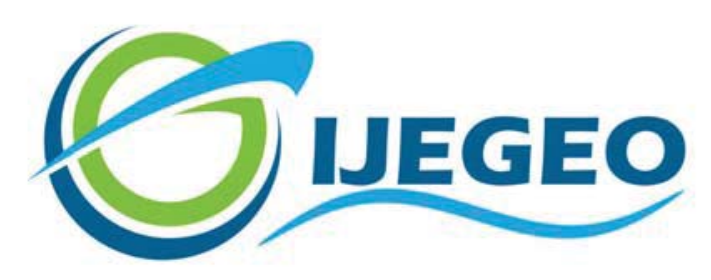

International Journal of Environment and Geoinformatics (IJEGEO) is an international, multidisciplinary, peer reviewed, open access journal.

\title{
Ecosystem Based Management Approach for Sea Water Management: Exıstıng Situation in Turkey
}

\section{Ömer Eyüboğlu, Huri Eyüboğlu}

\author{
Chief in Editor \\ Prof. Dr. Cem Gazioğlu \\ Co-Editors Prof. Dr. Dursun Zafer Şeker, Prof. Dr. Şinasi Kaya, \\ Prof. Dr. Ayşegül Tanık and Assist. Prof. Dr. Volkan Demir
}

Editorial Committee (June 2022)

Assoc. Prof. Dr. Abdullah Aksu (TR), Assoc. Prof. Dr. Uğur Algancı (TR), Assoc. Prof. Dr. Aslı Aslan (US), Prof. Dr. Levent Bat (TR), Prof. Dr. Paul Bates (UK), İrşad Bayırhan (TR), Prof. Dr. Bülent

Bayram (TR), Prof. Dr. Luis M. Botana (ES), Prof. Dr. Nuray Çağlar (TR), Prof. Dr. Sukanta Dash (IN), Dr. Soofia T. Elias (UK), Prof. Dr. A. Evren Erginal (TR), Assoc. Prof. Dr. Cüneyt Erenoğlu (TR), Dr. Dieter Fritsch (DE), Prof. Dr. Ç; Prof. Dr. Manik Kalubarme (IN), Dr. Hakan Kaya (TR), Assist. Prof. Dr. Serkan Kükrer (TR), Assoc. Prof. Dr. Maged Marghany (MY); Prof. Dr. Micheal Meadows (ZA), Prof. Dr. Nebiye Musaoğlu (TR), Prof. Dr. Masafumi Nakagawa (JP), Prof. Dr. Hasan Özdemir (TR), Prof. Dr. Chyssy Potsiou (GR), Prof. Dr. Erol Sarı (TR), Prof. Dr. Maria Paradiso (IT), Prof. Dr. Petros Patias (GR), Prof. Dr. Elif Sertel (TR), Prof. Dr. Nüket Sivri (TR), Prof. Dr. Füsun Balık Şanlı (TR), Dr. Duygu Ülker (TR), Prof. Dr. Seyfettin Tsaş (TR), Assoc. Prof. Dr. Ömer Suat Taşkın (TR), Assist. Prof. Dr. Tuba Ünsal (TR), Assist. Prof. Dr. Sibel Zeki (TR) 


\title{
Ecosystem Based Management Approach for Sea Water Management: Existing Situation in Turkey
}

\author{
Ömer Eyüboğlu ${ }^{1}$; ; Huri Eyüboğlu*2 \\ ${ }^{1}$ Ahi Evran University, Faculty of Education, Department of Science Education and Department of Science Teaching, Kirsehir, Turkey \\ 2*Department of Marine and Coastal Management, General Directorate of Environmental Management, Ministry of Environment and Urbanization, \\ Ankara, Turkey
}

* Corresponding author: H. Eyüboğlu

Received 06.07.2020 E-mail: huri.eyuboglu@csb.gov.tr Accepted 29.12.2021

How to cite: Eyüboğlu and Eyüboğlu (2022). Ecosystem Based Management Approach for Sea Water Management: Existing Situation in Turkey, International Journal of Environment and Geoinformatics (IJEGEO), 9(2):146-160. doi. 10.30897/ijegeo.1036013

\begin{abstract}
The overall aim of the Marine Strategy Framework Directive (MSFD) is to achieve or maintain Good Environmental Status (GES) within the marine environment. Turkey is in the process of using/developing an Ecosystems-Based Management approach for governance of its marine waters, based on the European Union (EU) Marine Strategy Framework Directive. The legislative history, conceptual approach, structure and content of the Directive, as well as some of its unique regulatory features are discussed here. The implementation of the MSFD represents a demanding task in the integrative assessment of marine ecosystems. Here we describe the implementation process, and we discuss the institutional framework and the main difficulties and challenges encountered so far, with emphasis on the Turkey context. This paper will provide a review of the existing institutional and legislative structure in Turkey relevant to the future implementation of the MSFD. Over the years Turkey has developed a robust body of Environment Law in general and a complicated institutional structure. One of the key priority elements for a successful implementation of the MSFD is the establishment of an effective framework for coordination and cooperation among national, regional and local authorities.
\end{abstract}

Keywords: Ecosystem Approach, Marine Strategy Framework Directive, Regional Seas Conventions

\section{Introduction}

The protection of our coasts and marine waters faces complex and multi-faceted problems. Our marine and coastal environment is under severe pressure from both land-based and ocean-based pollution sources (Barnes and Metcalf, 2010). EU legislation to protect the marine environment has been progressively implemented in many relevant areas: for instance the regulation of fisheries through the Common Fisheries Policy (Markus et al., 2011) or the control of input of nutrients and chemicals into the water through the Water Framework Directive (WFD). But these pieces of legislation, although crucial complementary tools to the protection of marine waters, contribute to the protection of the sea only from specific pressures resulting in a fragmented and sectoral approach.

The MSFD also reflects the commitment of the EU to implement general environment principles stipulated in international agreements. In addition to reflecting the set general environmental principles, the MSFD goes well beyond the existing international framework (Long, 2011). It lists ambitious targets, puts in place a robust implementation strategy clearly depicting the responsibilities of each actor, and most importantly it follows an integrated management approach that considers cumulative impacts instead of regulating specific issues and sectors in isolation. While the MSFD constitutes the first EU legislation specifically devoted to the protection of the marine environment, it should be considered alongside other EU policies and legislation, most notably the Water Framework Directive, the Nature Directives (Habitats and Birds) and the Common Fisheries Policy (CFP) (Holzwarth et al., 2009).

The MSFD also reflects the commitment of the EU to implement general environment principles stipulated in international agreement. The Marine Strategy Framework Directive (European Commission [EC], 2008) is the first encompassing piece of EU legislation specifically aimed at the protection of the marine environment and natural resources and creating a framework for the sustainable use of our marine waters. The Directive involves many implementation challenges, which are addressed through a Common Implementation Strategy between the Commission and the Member States and a regional approach to the implementation of its objectives.

This was some eight years after the entry into force of the Water Framework Directive ([EC], 2006), which provided a means to strengthen and support a range of issue- or sector-specific pieces of EU water-related legislation.

The Water Framework Directive approach was adapted and updated for the marine environment, providing a piece of legislation which is very demanding in terms of the breadth of assessment, but which allows considerable flexibility over the spatial resolution and monitoring 
frequencies used for assessment purposes (Borja et al., 2010). The MSFD promotes an Ecosystem Approach that can apply to all decision-making processes that affect the natural world - from those concerned with how we manage our seas, through to the day-to-day decisions of businesses, sea-users and consumers. The EcosystemBased Approach means the protection of ecosystem as a whole and integrated management of the ecosystem. The ecosystem approach emphasizes the handling of land, water and resources with a holistic management (Convention on Biological Diversity, 2000; SavunHekimoğlu and Gazioğlu, 2021, Savun-Hekimoğlu et al., 2021). Thus, it brings up primarily the protection of the environment factor among the economic activities. This approach is especially adopted by the European Union. The MSFD provides a framework within which EU Member States shall take the necessary measures to achieve or maintain Good Environmental Status (GES) within the marine environment by the year 2020 (Lyons et al., 2010; Simav et al., 2015; Gazioğlu, 2018; Akyüz, 2021).

The MSFD aims to achieve GES and to protect the resource base upon which marine-related economic and social activities depend. A "good environmental status" involves the provision of "ecologically diverse and dynamic oceans and seas which are clean, healthy and productive within their natural conditions, and the use of the marine environment is at a level that is sustainable, thus safeguarding the potential for uses and activities by current and future generations" (MSFD, Article 3(5)). The MSFD is also the environmental pillar of the EU's Integrated Maritime Policy (Bellas, 2014). Its overall aim is to promote sustainable use of the seas and conserve marine ecosystems (Burak et al., 2004, Casazza et al., 2007; Çetin, 2021). The application of ecosystem-base management in the seas has started to be addressed more recently and these needs and works have been brought to the agenda especially due to the decrease in fish stocks a global scale and the increasing deterioration in ecosystem status. The MSFD is a unique Directive based on Ecosystem-Based Management (Leeuwen et al., 2014). The ecosystem-based approach (EBA) has had a large impact on policies concerning the usage and management of natural resources and is also a starting point for the EU's Marine Strategy Framework Directive (Atkins et al., 2011). The Millennium Ecosystem Assessment Synthesis Report (Millennium Ecosystem Assessment [MEA] 2005) included statistics on this issue. In the same report, it is associated with the continuity of ecosystem services and the indirect and direct factors that cause change in the quality of people and their environment at global, regional and local levels (Figure 1).

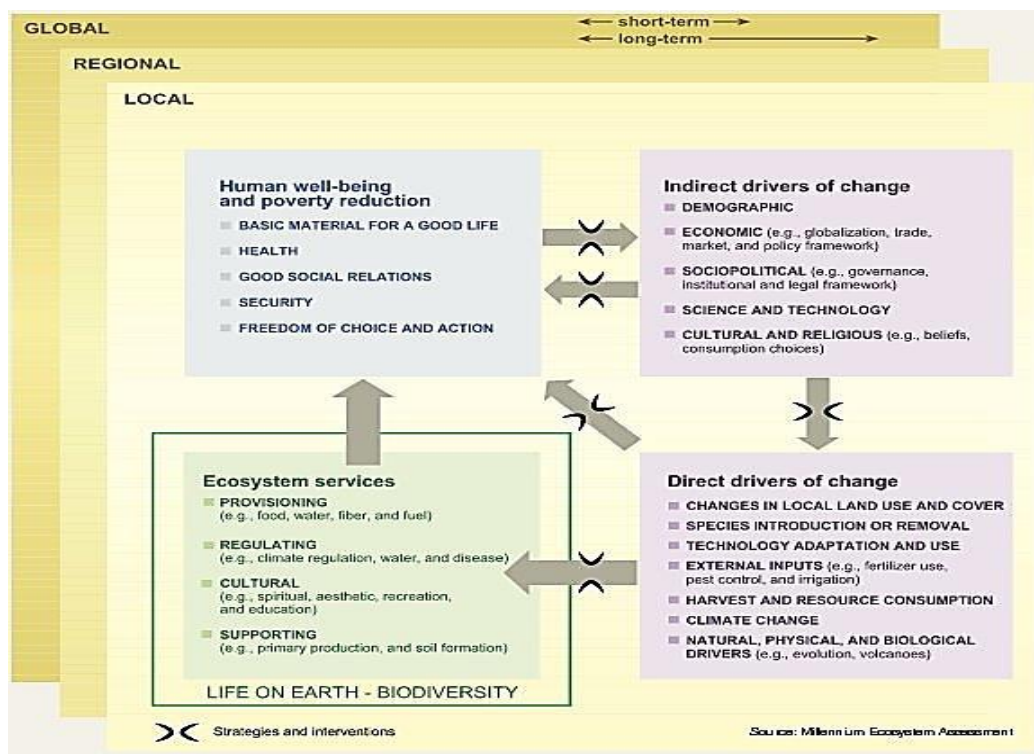

Fig. 1. Millenium Ecosystem Assessment Classification ([MEA], 2005).

Table 1. The descriptors of Good Environmental Status from Annex I of the MSFD

\begin{tabular}{ll}
1 & Biological diversity \\
2 & Non-indigenous species \\
3 & Commercial fish\&shellfish \\
4 & Food-webs \\
5 & Eutrophication \\
6 & Sea-floor integrity \\
\hline 8 & Hydrography \\
9 & Contaminants \\
10 & Contaminants in seafood \\
\hline 11 & Litter \\
\hline
\end{tabular}




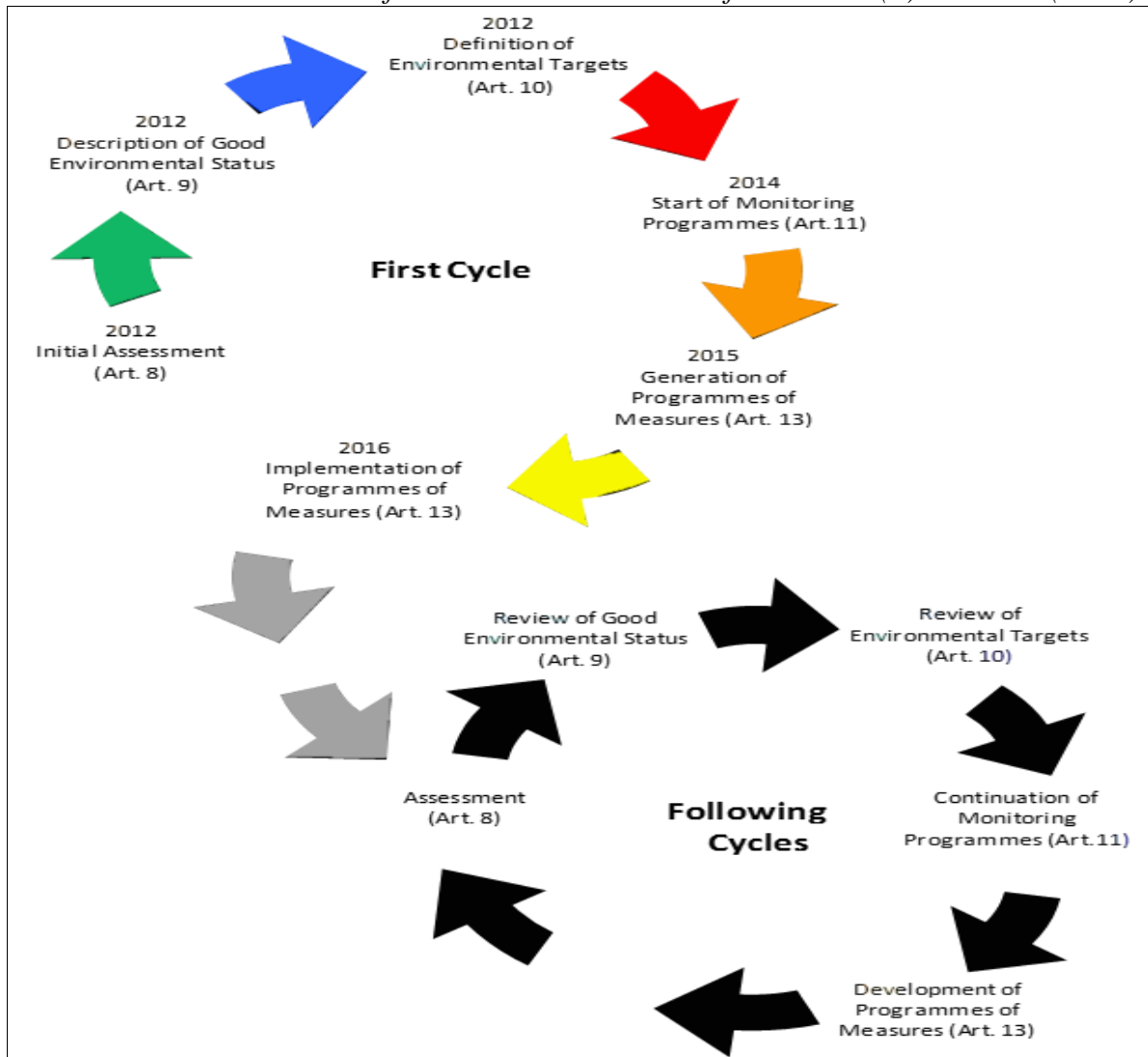

Fig. 2. The MSFD management cycle ([EC], 2011).

\section{The Basic Approach in the Marin Strategy Framework Directıve}

As described in the Directive (Article 3 (5)) Good Environmental Status is defined on the basis of the qualitative descriptors in Annex I of the Directive. The Commission has adopted for the assessment of the status and the definition of the targets regarding to 11 GES objectives with 29 main and 56 indicators (Berg et al., 2015). Article 10 of the MSFD emphasizes that the objectives of the GES should be measurable, which are divided into different layers as status, pressure, impact and operational objectives ([EC], 2010). GES is to be assessed on the basis of 11 descriptors contained in Annex 1 of the Directive (Table 1).

Data used for any given assessment may vary between regional seas. Later steps of integration across scientific indicators, criteria and elements which lead to conclusions on the overall status of the main components should be harmonised to ensure consistent application of the criteria set out in the ([EC], 2017). It is expected that the descriptors / principles and indicators mentioned above will be used in defining the GES and determining its objectives. An adaptive and repetitive management approach was adopted in the provision of 2020 targets. As a consequence MSFD envisages an updating process of marine strategies on a regular basis, based on a six-year cycle (Figure 2).

The cyclic process provides regular opportunities to improve the knowledge base, review the environmental status of marine waters and on this basis to review the determination of GES, the environmental targets needed to achieve GES, and the suitability and effectiveness of their, monitoring programs and program of measures.

There exist different designated competent authorities for different aspects regarding the protection of the marine environment in Turkey. Studies conducted in Turkey Prevention of marine pollution is among responsibilities of many institutions and organizations in Turkey, in the context of activities carried out in relation to understanding the MSFD it is understood that lack of coordination and cooperation among institutions leads to conflicts regarding scope of authority while some tasks were not allocated to any institution (Beken, 2017).

\section{Material and Method}

The Marine Strategy Framework Directive includes the duties and responsibilities of many institutions and organizations in Turkey within the scope of 11 descriptors. On the other hand, the directive also includes cooperation with the Barcelona and Bucharest Conventions, one of the regional maritime conventions. In this study, the legislative structures of institutions and organizations were evaluated. In addition, the current developments of regional marine Conventions within the scope of the relevant Directive have also been taken into account. In recent years, very important steps have been taken in Turkey within the scope of the implementation of the MSFD with the aim of protecting the marine environment. In this framework, in evaluating the current 
situation regarding the implementation of MSFD in Turkey, national legislations, projects, strategy documents, action plans; EU and international policies/directives, Regional Sea Conventions to which our country is a party, and other relevant international conventions have been taken into account (Figure 3). Italy and Slovenia were visited on May 7-11, 2017 in Study Tour. 3 institutions were visited in each country: Italy the Ministry of the Environment, Land and Sea, the Institute for Environment Protection and Research (ISPRA), Trieste Chamber of Commerce, and Slovenia the Ministry of Environment and Spatial Planning, the National Institute for Biology, the Institute for Water of the Republic of Slovenia.

A total of 14 participants joined the study tour from different institutions. Workshops were organized by the Ministry of Environment and Urbanization for the beneficiaries and stakeholders to share experiences between EU and Turkish experts. The aim of the workshop is to focus on Turkey's legal and institutional framework regarding this Directive with the aim of ensuring coordination, communication and cooperation among stakeholders in accordance with the provisions of the Marine Strategy Framework Directive. This workshop focused on working with major players to clarify their roles in the implementation process and attempted to shed light on the state of play of the major players. The workshop was interactive and participants' direct engagement was ensured. Five international experts from five different countries guided the participants with their presentations and through their roles as moderators. Interministerial coordination (political structure) is of a vital importance for future work because it will enable communication and transfer of knowledge between science and policy.

Therefore, the establishment of a MSFD Coordination Committee and corresponding structure is highly recommended as it will assure a flow of knowledge and approaches between science and policy to support the process in communication to the political level required for a successful implementation of MSFD in the future. In this study, the meetings coordinated by the Ministry of Environment and Urbanization and the outputs of the MARinTURK project were used. Close communication and dialogue between Ministries has been maintained during the study period. The communication was based on email, phone, and direct meetings.

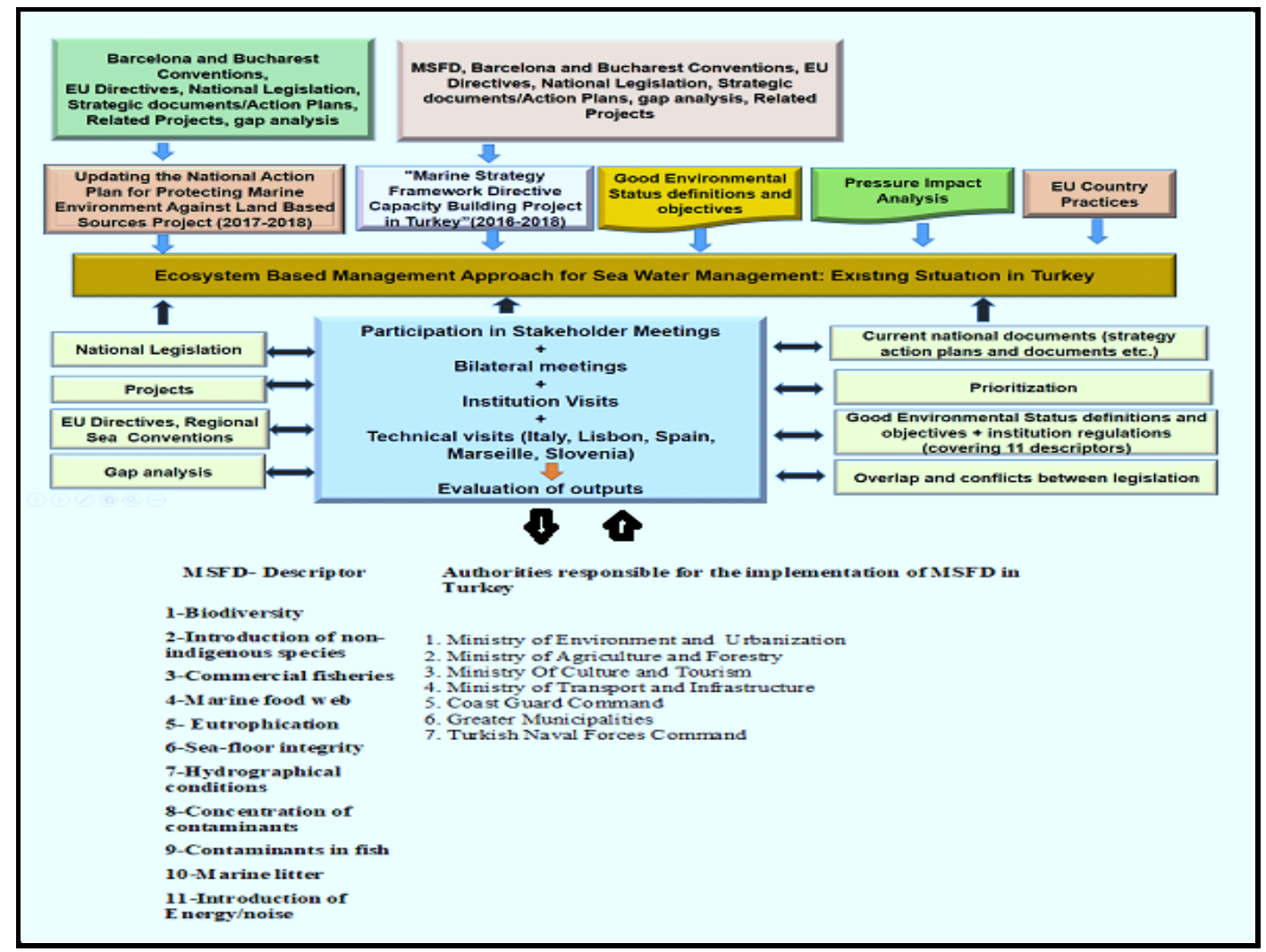

Fig.3. Current situation assessment and roadmap for the implementation of MSFD in Turkey

While the MSFD constitutes the first EU legislation specifically devoted to the protection of the marine environment, it should be considered alongside other EU policies and legislation, most notably the Water Framework Directive (WFD), the Nature Directives (Habitats and Birds), the Common Fisheries Policy (CFP) and the Maritime Spatial Planning Directive (MSPD). These directives have been consulted with focal points and working groups of the relevant ministries. It has been evaluated together with the descriptors of the MSFD Directive (Figure 4). The compatibility of the descriptors and the directives and the gaps in this matter were revealed by the working groups. Meetings were held with municipalities, institutions and non-governmental organizations in order to implement the actions produced as a result of communication and coordination of necessary information. In order to focus on environmental problems that require expert knowledge within the scope 
of each descriptor, contact has been made with academic and research institutes. Considering that the study area also covers the Barcelona and Bucharest Convention, coordination has been ensured with the Universities located in the Black Sea, Mediterranean and Aegean Seas.

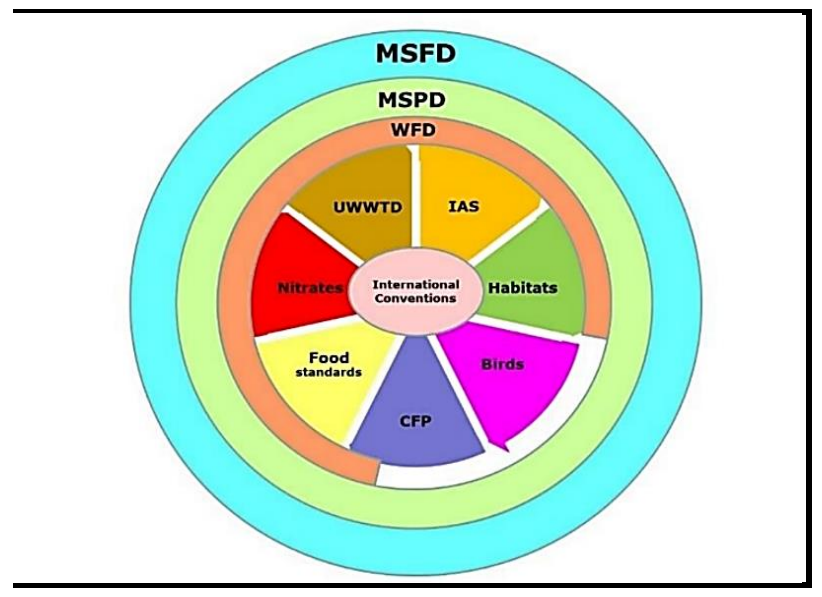

Fig. 4. Illustration of the MSFD and WFD's framework nature for environmental protection through association with various other policies and international conventions (only a selection of relevant policies are shown: IAS Regulation (EU) No 1143/2014 on invasive alien species; Habitats - Habitats Directive; Birds - Birds Directive; CFP - Common Fisheries Policy; Food standards - Regulation (EC) No 1881/2006 on contaminants in foodstuffs; Nitrates - Nitrates Directive; UWWTD - Urban Waste
Water Treatment Directive). The Maritime Spatial Planning Directive (MSPD) has a similar spatial scope to MSFD.

In Turkey, there is a quite large and comprehensive environmental legislation in place and each day new regulations are incorporated into it within the scope of adjustment to the EU legislation. However, the relevant legislation is concerning numerous sectors and institutions and it has a complex structure. The number of institutions authorized to implement this legislation is quite high. Sporadic structure of the legislation and authority to many different institutions and organizations causes a mess in terms of ownership of environmental problems and in institutional structure. With the coordination with the ministries, the priorities of the sectoral policies, strategies and action plans of the relevant legislations were revealed and the overlaps and problems between the legislations were determined. In this process, the responsible institutions and organizations for each identifier have been determined and the relevant legislation has been evaluated. Especially in relation to marine activities and protection of the marine environment there are overlaps between the "Ministry of Environment and Urbanization" and "Ministry of Agriculture and Forestry". Over the years Turkey has developed a robust body of Environment Law in general and a complicated institutional structure. The application area of the directive is the Mediterranean and the Black Sea, which includes the regional marine conventions to which Turkey is a party (Figure 5).

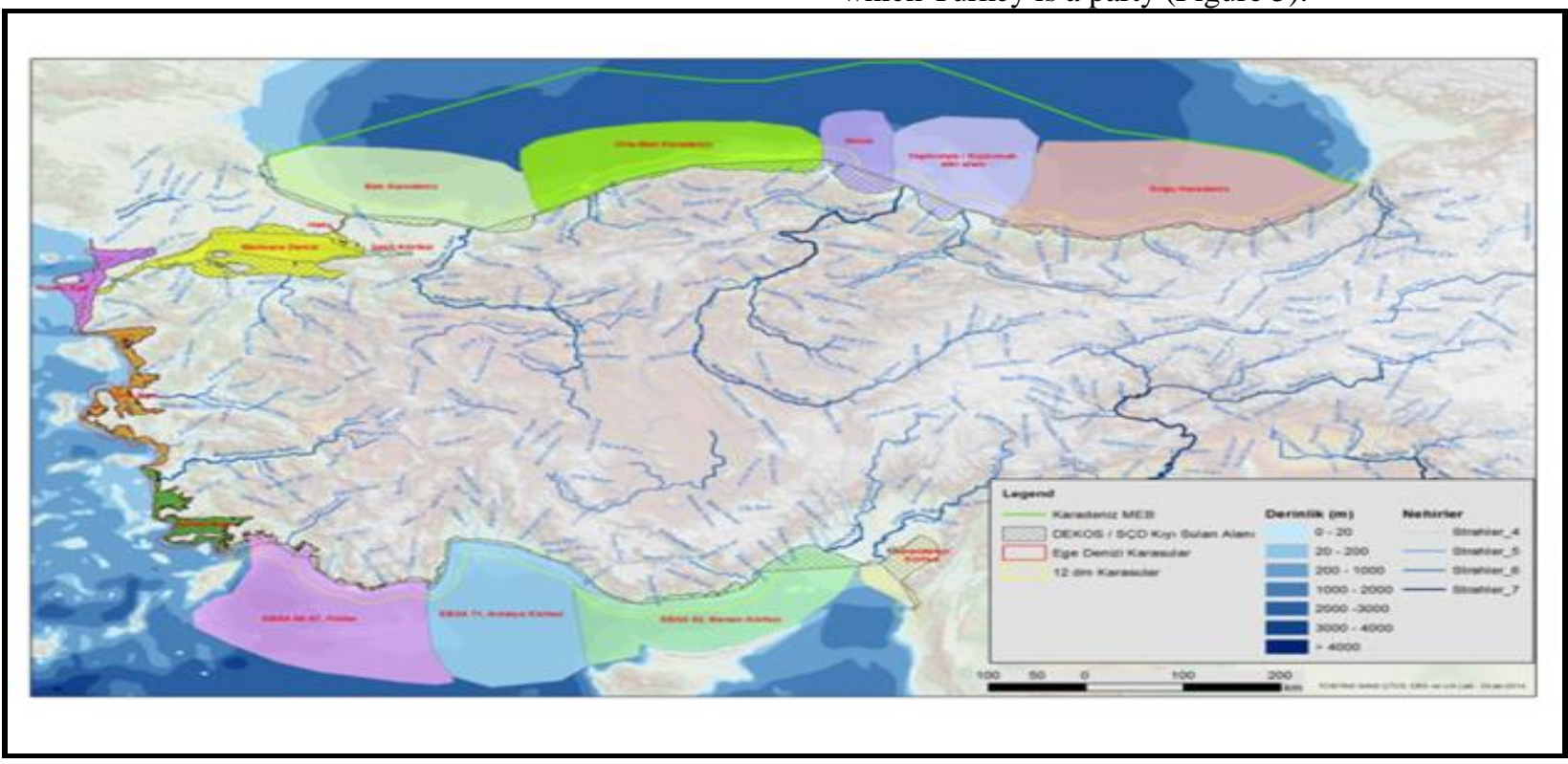

Fig.5. Study area in Turkey (Beken ,2017).

In this study, the basic dimensions of Marine Strategy Framework Directive management practices and the lessons learned in Turkey were evaluated in terms of the legal and institutional framework.

\section{Results}

In Turkey, the timeframe for the establishment of the major components of the MSFD (Initial Assessment, establishment of targets and definition of GES,
Monitoring Programmes, PoMs) has been much less than the six years of the MSFD. This has resulted in a disruption of the sequence in which the MSFD is intended to be conducted. In particular, the development of Turkish-specific environmental targets remains at a necessarily early draft stage, requiring further discussion, evaluation and feasibility studies at technical and governmental levels (MARinTURK, 2017).There is lack of coordination of monitoring activities in marine waters in accordance with MSFD requirements in Turkey. 
Monitoring studies need to be continuous and continued over an extended period of time (Beken, 2017). Thus, there is a need for greater coordination amongst ministries in terms of funding relevant monitoring sub-program, what is monitored, who undertakes the monitoring and the locations/frequency of such monitoring. Monitoring needs to be able to determine the status of whole seas, including changes in pressures. As in particular, the development of Turkish-specific environmental targets will require further discussion, evaluation and feasibility studies at technical and governmental levels before a commitment to a final set of targets and indicators can be made. Therefore, the task of linking measures to established environmental targets is difficult and ultimately of no immediate value at this point in time.

Based on the initial assessment, determination of good environmental status and definition of targets, measures have to be identified in order to address human activities that have an impact on the marine environment and to improve or maintain the status of the marine environment (Criese et al., 2015). If the existing measures are not sufficient, supplementary and / or new measures need to be identified. The proposed program should be revised with a more in depth analysis to investigate to which extent existing measures contribute to the achievement of the environmental targets and investigate and refine definition of gaps.

The development and implementation of Program of Measures (PoMs) needs involvement of competent authorities based on an assignment of activities. Designing PoMs is an iterative process involving the repetition of a series of steps involving the participation of stakeholders and political decision-making (Giakoumis and Voulvoulis 2019). There are numerous similarities in the objectives and implementation processes of the WFD and the MSFD, from the continuous monitoring and the establishment of PoMs to the adaptive management approach aiming to provide a long-term and sustainable system for water protection. The links between the MSFD and the WFD are particularly strong when it comes to the control of pollution from land-based sources and the protection of coastal areas (Borja et al., 2010).

Since MSFD and WFD are closely linked, the first step proposed is to align timescales between the work that has already been undertaken within Turkey with that of the EU 6-year MSFD cycles. Furthermore, many of the 'coastal waterbody' quantitative thresholds should originally be set under the WFD ([EC], 2000).

The achievement of the WFD objectives through the PoM will significantly contribute to the achievement/maintenance of the good environmental status of marine waters. The coordination of planning and implementing measures between the two Directives is therefore essential to their successful implementation (Beken et al., 2013). WFD approach was adapted and updated for the marine environment, providing a piece of legislation which is very demanding in terms of the breadth of assessment, but which allows considerable flexibility over the spatial resolution and monitoring frequencies used for assessment purposes (Hoeya et al., 2010).

A combined MSFD / WFD Program of Measures should be produced to avoid duplication and possible confusion between the two pieces of legislation. PoMs need to be coherent and coordinated across the relevant marine region. It is therefore important to discuss and agree within Regional Sea Conventions about common measures, especially in cases where common action would improve effectiveness of implementation (Marine Litter Action Plan agreed by the Barcelona Convention, could be considered as a good example of this requirement).Member States need to ensure that policy measures are cost-effective, and carry out impact assessments, including cost-benefit analyses, prior to the introduction of any new measures (Bertrama et al., 2014).

A preliminary assessment has focused at a high-level on the approaches used by the Member States for the ESA (Semeniene, 2017). The lack of available information and the existence of data gaps were acknowledged by the majority of Member States. For the ESA, most Member States have used the Water Accounts approach ([EC], 2017).

In Turkey, both national and international studies have been carried out in order to understand the Directive and identified the program of measures for The Mediterranean Sea and The Black Sea taking into account relevant national legislation, EU directives, strategy documents, action plans, policies, institutional restructures and updates for achieving the Good Environmental Status and objectives. For the first time, the socio-economic analysis study has been conducted for the country's seas regarding the effectiveness of the measures determined within the framework of the descriptors of the Marine Strategy Framework Directive. Few marine ecosystem services assessment studies are available in Turkey, so ecosystem services method for the cost of degradation could not be applied (Başak Dessane, 2017).

The socio-economic analysis of the use of marine waters, required by the MSFD, was performed by Turkey using the Marine Water Accounts approach, which included three types of macro-economic data for each maritime sector: production value, added value and employment. Moreover, the analysis of the cost of degradation of the marine environment was performed using the Cost-based approach, where the expenses of various public bodies for remedying environmental damage and impacts are included. While, as acknowledged in Turkey's initial assessment, this provides a good snapshot of actual costs sustained to remedy environmental damage to the marine environment in Turkey, however Turkey acknowledges that it misses the loss of social wealth derived by the degradation (Kocaman, 2017).

The description of the Drivers, Pressures, State and Impact of the marine water use obtained under Art. 8 MSFD will therefore be an important input in setting environmental targets (Turner et al., 2010). The socioeconomic analysis has been conducted by taking into 
consideration the program of measures and It has been determined that many data were incomplete for socioeconomic analysis.

The key institution for the implementation of environmental measures for the marine environment, in general, is the Ministry of Environment and Urbanisation. In addition, the Ministry of Transport and Infrastructure has the authority and responsibility for the prevention of marine pollution resulting from all type of ships and similar marine vessels, which operate in Turkish marine waters and inland waters. There are other Ministries and agencies that also have responsibilities under the existing institutional framework. For example, the Ministry of Agriculture and Forestry has important responsibilities for marine protected areas and wetlands. There exist different designated competent authorities for different aspects regarding the protection of marine environment in Turkey.

The Ministry of Environment and Urbanism (MoEU) is also well placed to serve as the competent authority for cooperation and coordination with other countries concerning marine strategies (Oral, 2017). Turkey is intending to implement ecosystem-based environmental management of its national marine waters in line with the European Union Marine Strategy Framework Directive.

Marine monitoring programs, like other environmental monitoring programs represent a compromise between frequency and spatial coverage/resolution within a given budget. The monitoring activity should provide the data that will support the appropriate indicators that will help to assess whether good environmental status has been achieved or is being maintained.

Hence, it will be possible to measure the progress in achieving environmental targets and to assess the effectiveness of the measurements taken to achieve or maintain the good environmental status (JRC Scientific and Policy Reports, 2014). Most Member States have based their monitoring programs on existing monitoring undertaken under other EU legislation or through their respective Regional Sea Conventions (Zampoukas et al., 2012). Article 6 of the MSFD acknowledges the longstanding role of the Regional Sea Conventions (RSCs) in Europe, where cooperation among relevant countries has been taking place to protect the seas for more than 30 years, and requires EU Member States to coordinate their efforts through these existing structures ( Hoof et al., 2014).

The Water Framework Directive, the Habitats Directive and the Common Fisheries Policy Regulation are the pieces of EU legislation most commonly linked to the MSFD monitoring programs (Craglia et al., 2010). In that sense, it can be considered that monitoring programs are generally consistent with other relevant legal obligations.
The Marine Strategy Framework Directive requires the European Union Member States to establish ecological monitoring programs covering all sea waters and expand existing monitoring (Zampoukas et al., 2013).

Monitoring fact sheets and method manuals for programs and sub-programs should be developed in line with MSFD requirements and recommendation from (Walmsley et al., 2017). Implement recommended approach to data aggregation by Walmsley and other recommendations developed on regional level are important. Compared to most EU Member States, Turkey's organization of marine environmental monitoring is relatively complex, with monitoring divided between a range of regional authorities, institutions ministries, universities and TUBITAK, the national scientific advisory service. Thus, the importance of a national marine monitoring committee, with representatives from all such institutions should not be under-estimated. In terms of MSFD requirements, there are two major considerations which monitoring has to provide data for:

\section{Assessment of achievement of (or distance from) Descriptor-specific definitions of Good Environmental Status (GES) \\ Assessment of achievement of (or distance from) Environmental Targets.}

Unlike, EU Member States, Turkey has opted to include information collation/knowledge improvement within its Environmental Targets, rather than leave these directly to the monitoring programme revision step of Directive implementation.

\section{Studies for Improvements in Institutional Structure in Turkey}

A group of competent authorities exists in Turkey concerning marine monitoring and management, so in some cases the authority/responsibility is not clear. However, it is clear that improved coordination of monitoring programs would benefit all. Wider sharing of the data produced should be as essential. In Turkey, marine environmental monitoring is complex, since existing monitoring is divided between a large number of ministries, universities, local governmental bodies and NGOs. Some of this monitoring is routine and repeated on a regular basis, while other work is project based, and thus of limited sustainability. Unlike, EU Member States, Turkey has opted to include information collation/knowledge improvement within its Environmental Targets, rather than leave these directly to the monitoring programme revision step of Directive implementation (Beken, 2017). Similarly, outputs from the Integrated Pollution Monitoring in Marine Waters Programme will also guide future monitoring studies (MARinTURK, 2017). Taking into account the Marine Strategy Framework Directive and the above-mentioned studies, the Turkish Monitoring Program was divided into 20 sub-programs as given in Table 2. 
Table 2. Turkish Monitoring Programme was divided into 20 sub-programmes.

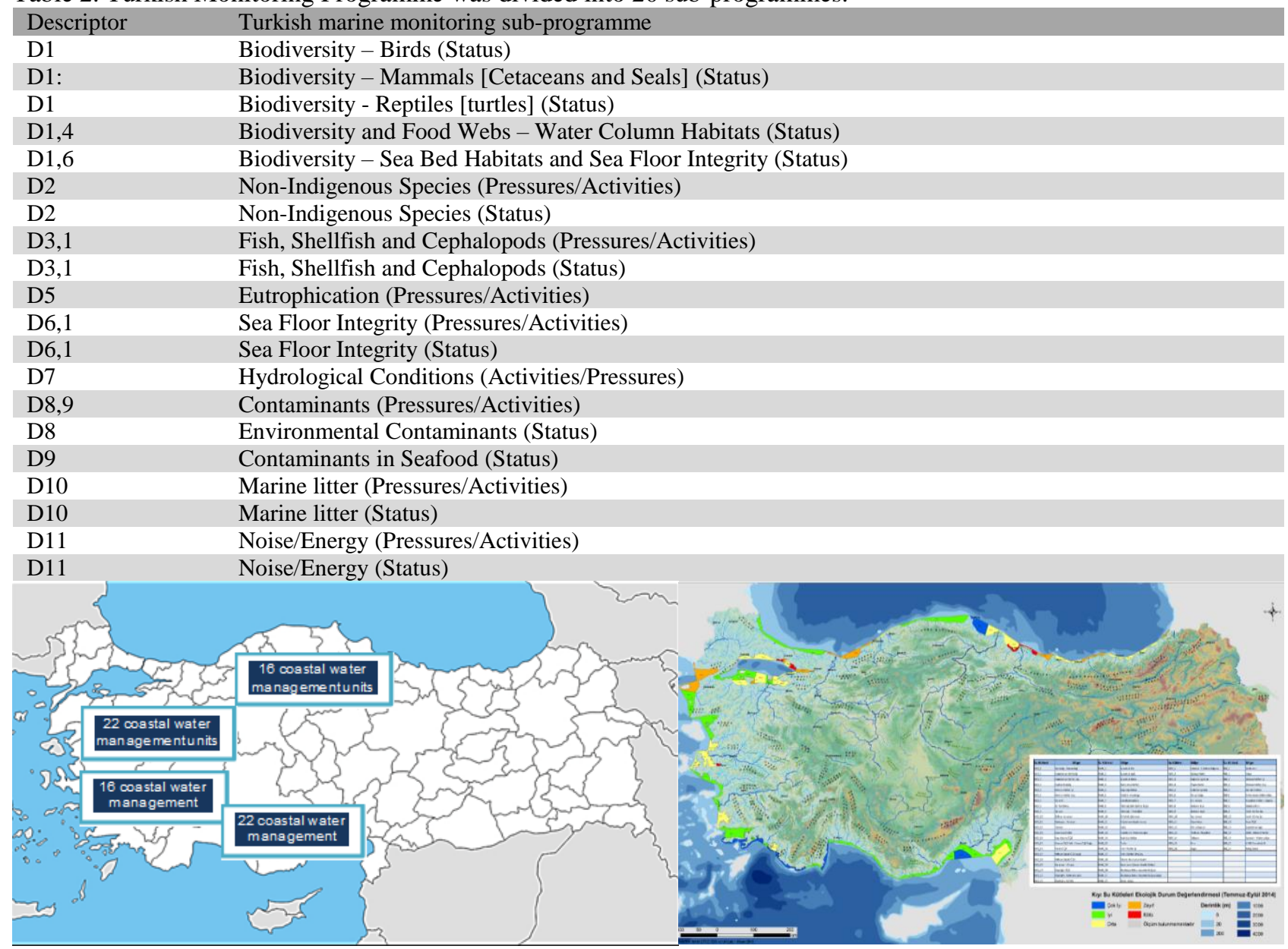

Fig. 6. Coastal Water Management Units in Turkey

Turkey coordinates the required studies to attain protection of coastal regions and seas based on the international conventions where it is a party (Barcelona and Bucharest Contracts, Protocols of Land-Origin Pollutants), national legislations and the relevant EU Directives.

In this context, the first project manifesting the current situation and needs in the framework of MSFD implementation is Project of Sea and Coastal Water Categorization. In "Marine and Coastal Waters Quality Status Determination and Classification Project", a general framework has been established for MSFD implementation in Turkey. "Marine and Coastal Waters Quality Status Determination and Classification Project" was carried by TUBITAK-Marmara Research Center under the coordination of Ministry of Environment and Urbanization. In this Project, within the framework of the Maritime Strategy Framework Directive adopting an ecosystem based approach; current situation of the marine environment was studied whilst needs and gaps were determined fort he necessary analyses. As a EU candidate member, although Turkey does not have an obligation to implement the Directive, some preparatory steps have been taken by the end of this Project, which include;

A preliminary assessment of Turkish season the good environmental status descriptors stated in the Maritime Strategy Framework Directive. Preparation of pressure, pollution, ecosystem quality maps. Classification of coastal water management units has been defined in accordance with the Water Framework Directive by evaluating coastal water typologies, pressure and situation information for all seas (Beken et al.,2014). Seventy-six water management units were determined accordingly as given in Figure 6.

A preliminary assessment of the situation in Turkish seas has been made in regard to good environmental status descriptors, identified in European Union Marine Strategy Framework Directive. GES definitions have been set generally and the process of development of environmental objectives specific to Turkey should be considered as a draft. The development of Turkishspecific environmental targets presently remains at a necessarily early draft stage, requiring further discussion, evaluation and feasibility studies at technical and governmental levels before a commitment to a final set of targets and indicators can be made. A group of competent authorities exists in Turkey concerning marine monitoring and management, so in some cases the authority/responsibility is not clear.

However, it is clear that improved coordination of monitoring programmes would benefit all. Wider sharing of the data produced should be as essential. "Document of Turkish Marine Research Strategies", legitimized by the Cabinet and announced in the Official Gazette on October 
2,2014 , is the first official document in Turkey, referring to Marine Strategy Framework Directive. The Strategy aims to strengthen Turkey's maritime research activities in order to be competitive with international standards. "Office of Navigation, Hydrography and Oceanography" and based on the Law on Navigation and Hydrography Services Turkey adopted The Turkish National Marine Research Strategy for 2014-2023.

The primary research topics of National Marine Research Program ([NMRP], 2017), composed pursuant to Turkey National marine research strategy's action plan and is still in a draft form, are biodiversity research, discovery and sustainable management of marine resources, establishment of monitoring and observation systems, and these will ensure development of research projects, which will enable implementation of MSFD under many headings with determined deficiencies. Of relevance to the MSFD are the following:

To provide for an effective resource management for the stock assessment of marine living resources under the pressure of overexploitation, pollution,

- To provide scientific support for the monitoring of water quality and ecosystems for the development of national environmental policies, To contribute to achieving the objectives of good environmental status for our seas and good water status for coastal waters and the sustainable use of the seas through the framework of quality criteria determined by an integrated approach,

- To support decision-makers by developing integrated management models for the sustainable use and protection of the seas,

- To develop the infrastructure for the sustainable management of marine protected areas and identification of marine habitats,

The Strategy further established an Executive Committee with the responsibility of meeting at least once a year to review the work (Elge, 2017).National Biologic Diversity Strategy and Action Plan (2007) defines actions on the protection of coasts and marine biodiversity. National Biologic Diversity Strategy and Action Plan consists of objectives and actions that will affect all sectors playing a role on protection, management and use of biological diversity directly or indirectly. "Program of Integrated Monitoring at Seas" is executed to establish a basis for determination of national sea and coast management policies and strategies in the scope of regional marine contracts, to set objectives of good ecological situation and environmental stage in regions covering coastal and offshore waters and to check these objectives at specific intervals. This management model is based on the principle of check, review and update of management plans developed according to the set objectives. The Program is designed to satisfy most of the MSFD descriptors. The monitoring program is reviewed periodically every 3 years, revised to develop GES definitions and objectives and to meet new national/international requirements, and it covers pilotscale research and application studies as well.
By "Project of Standardization in Marine Monitoring" (2015-2017), Marine Monitoring Guidelines (MMG, 2017) is issued in parallel to MSFD monitoring subprograms and Document of National Monitoring Strategy (2017) is released. There are 12 guidelines, including guidelines of trawler use in biological diversity sea litter studies, guidelines of benthos monitoring, guidelines of sea litter monitoring, guidelines of sea mammals, guidelines of hydrographical conditions, guidelines of inorganic pollutant monitoring, guidelines of macro-algae and seagrass, guidelines of microbiologic pollutant monitoring, guidelines of organic pollutants, guidelines of eutrophication monitoring, guidelines of plankton monitoring, and guidelines of underwater noise monitoring. With these guidelines, it is aimed to manage standardization in the stages of sample collection, analysis, evaluation and reporting in marine monitoring. "Updating the National Action Plan for Protecting Marine Environment against Land Based Sources Project (LBS NAP Project)" has been realized by the Ministry of Environment and Urbanization in 2016-2017.

In this study, National Action Plan for Protecting Marine Environment against Land Based Sources has been updated considering the relevant EU Directives and Ecosystem Based Approach Management National Action Plan for Protecting Marine Environment against Land Based Sources has been updated for following ecological objectives: eutrophication, contaminants and marine litter covering 18 coastal basins. Evaluation of existing pollution control measures, existing legislative frame, revising policies and strategies on basis of river basins have been finalized within the scope of this Project (Avaz, 2017). In the light of these studies, as rewardingly with the aim of the preparation of "National Marine Environment Strategy Document", which includes the policies and measures that will ensure a good environmental status for all activities that have an impact on the marine environment, a project named Turkey Creation of Marine Environment Strategy was initiated by TUBITAK/MAM under the coordination of the Ministry of Environment and Urbanization (2018-2020). In the implementation of the National Marine Environment Strategy; It is necessary to participate in the management model of all relevant economic sector practitioners and stakeholders in order to regulate the human activities that continue in our coastal and maritime waters with ecosystem-based management principles and to meet the targeted Good environmental Status with the measures to be taken.

Within the scope of the project it is aimed to; supply of coordination between the institutions in order to achieve good environmental status and work jointly on the issues when needed, monitoring of the works carried out by international organizations in an effective and efficient way and establishment of working groups in order to ensure the management and coordination of those works in coordination with the relevant institutions and organizations. The names and duties of the technical groups under the Monitoring Working Group to be established could be regulated in accordance with EU practices ([EC], 2017) as given in Figure 7. 
In Ecosystem Based Management Model, it is required that;

administrative coordination and administrative structure / legislation to facilitate this operation,
- a coordinated technical structure (consortium) consisting of related establishments,

- ensuring the continuity of the consortium capacity by increasing capacity,

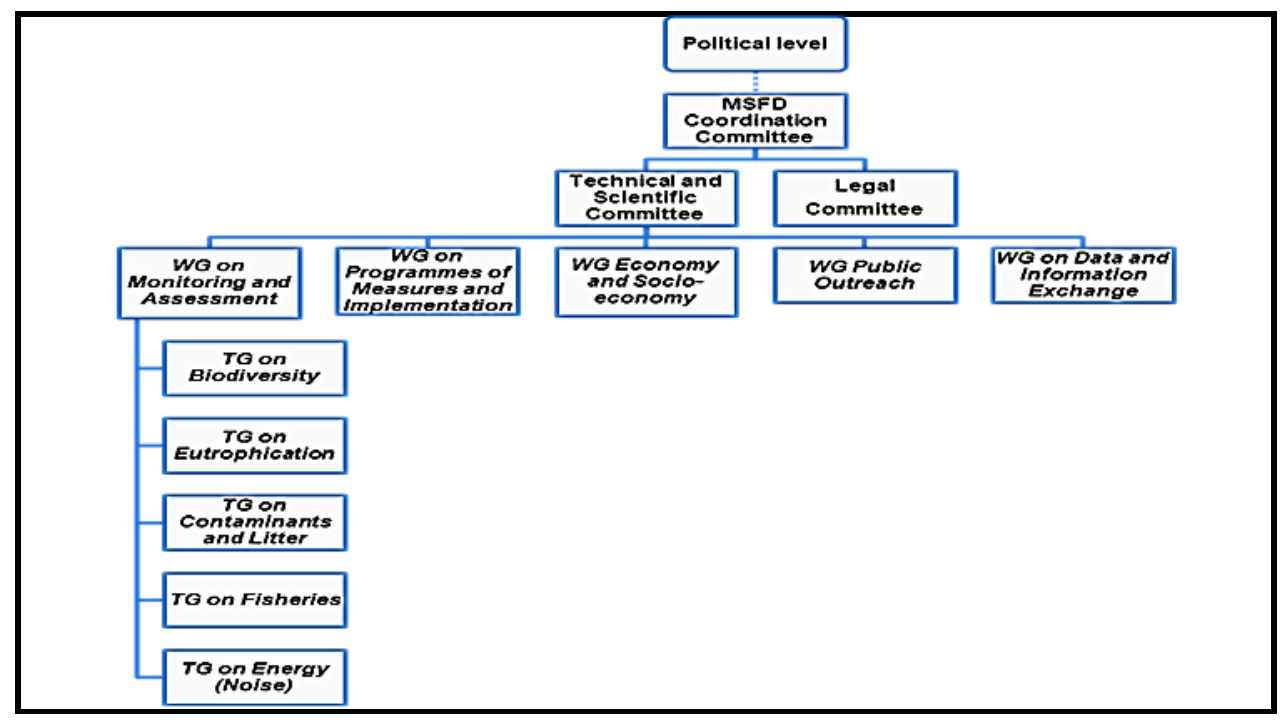

Fig. 7. Working Structure for the implementation of the MSFD ([EC], 2017).

Within the framework of the Convention on the Protection of the Mediterranean Sea against Pollution (the Barcelona Convention), to which Turkey is a party, a close cooperation among the riparian countries is carried out in order to ensure the conservation and sustainable use of the Mediterranean sea environment. The Conference of the Parties organized under the Barcelona Convention is held every two years and the 18th Meeting of the Parties is held on 3-6 December 2013 in Turkey (Istanbul).

At the 18th Meeting of the Conference of the Parties of the Barcelona Convention (COP) held in 2013, an integrated list of Mediterranean Good Environmental Status common indicators and related targets, associated with the 11 Operational Objectives and Indicators were agreed. The United Nations Environment ProgrammeThe Mediterranean Action Plan (UNEP-MAP)'s Integrated Monitoring and Assessment Programme (Decision IG.22/7) (IMAP) was adopted by the 19th COP of the Barcelona Convention in 2017 and is the latest framework for monitoring and assessment in the Mediterranean.

This sets out 27 Common and Candidate Indicators which are related to the Ecological Objectives for the region. A Quality Status Report (QSR) is prepared for 2017, which will contribute towards MSFD. Turkey is also a member of the Bucharest Convention/Black Sea Commission (BSC): Black Sea Strategic Action Plan (BS SAP) 2009 was approved. The underlying philosophies of the MSFD and the BS SAP are different but complementary.

The BS SAP is based on targeting environmental priority problems for the Black Sea; its management targets do not directly state what the environmental status should be as a result of the activities undertaken under the BS SAP. In the framework of the Final Diagnostic Report 2010 (produced by the BSC Permanent Secretariat (PS) with the financial support of the European Environment Agency (EEA), a summary of the suitability of Black Sea data (of BSIS and external data sources) for calculation of BSC and EEA indicators and MSFD descriptors was prepared. As a result, some indicators were identified for almost all MSFD descriptors (except Descriptor 10).

In 2015, the BSC approved regional reporting indicators, to be reported annually to the BSC by the Advisory Groups to the BSC. The indicators are grouped in six tables, according to the thematic focus of Advisory Groups (e.g. Biodiversity, Land-based pollution etc.). Some of the agreed indicators are also quite relevant for the MSFD implementation process.

- The BSC approved the Black Sea Integrated Monitoring and Assessment Programme (BSIMAP) in October 2016. BSIMAP was developed in the light of the MSFD, taking into account descriptors, GES and targets. The regional reporting indicators identified previously became part of BSIMAP. Its adoption is a positive step, as it contributes to the harmonization of the reporting format across countries and could provide the basis for comparing general environmental trends of the Black Sea marine environment.

- However, more efforts are needed towards harmonization of methodological approaches in determining GES by descriptors, criteria and/or indicators at the regional level, in order to better align the MSFD, BS SAP 2009 and BSIMAP implementation processes in the future.

While the MSFD constitutes the first EU legislation specifically devoted to the protection of the marine environment, it should be considered alongside other EU policies and legislation, most notably the WFD, the 
Nature Directives (Habitats and Birds), the Common Fisheries Policy (CFP) and the Maritime Spatial Planning Directive. At the regional level Turkey is a member of Table 3. Regional Sea Conventions (RSCs) - relevant activities
UNEP Regional Seas Black Sea Programme and its Black Sea Commission as well as the Mediterranean Action Plan Programme (Table 3).

Regional Sea Convention
protection of the Black Sea
Barcelona the
(UNEP/MAP) for the protection of
the Mediterranean

Main relevant activities
A new Strategic Action Plan for the Environmental Protection and Rehabilitation of the Black Sea (BS SAP) was adopted in April 2009. Similar to the other RSCs, the BS SAP contains an ecosystem approach and gives a framework for regional coordination, aiming for coherence with the MSFD. The activities relating to the BS SAP are developed within the Advisory Groups, which have been working e.g. on the development of indicators.

UNEP/MAP adopted the Ecosystem Approach and the roadmap for its implementation in 2008, which are closely related to the MSFD. The Ecosystem Approach (EcAp) Coordination Group coordinates UNEP/MAP activities for the implementation of the Ecosystem Approach. The Integrated initial assessment of the Mediterranean Sea and State of the Mediterranean marine and coastal environment reports contribute towards an initial assessment of the MSFD. A number of multiannual action plans, which promote the adoption of measures to achieve the Ecological Objectives have also been adopted. Implementation of the EcAp/MSFD in the Mediterranean is also supported by many research projects which are managed externally, such as for example Policyoriented marine Environmental Research for the Southern European Seas (PERSEUS).
Many EU projects are geared towards the implementation of the MSFD by EU Member States in coordination with the RSCs. For example, in 2013-2015 the European Commission funded a New Knowledge pilot project in the Mediterranean and Black Sea (IRIS-SES) to assist EU Member States in developing coordinated monitoring programmes in these sea regions.

One of the main outcomes of the project was the development of catalogues of current environmental monitoring in the different sea regions to assist EU Member States in their MSFD Article 11 reporting. Regional coordination of the MSFD in the Mediterranean and in the Black Sea marine regions is also supported by the Commission through projects aiming to deliver technical and administrative support in the implementation of the MSFD.

The MSFD reflects the commitment of the EU to implement general environment principles stipulated in international agreements. It lists ambitious targets, puts in place a robust implementation strategy clearly depicting the responsibilities of each actor, and most importantly it follows an integrated management approach that considers cumulative impacts instead of regulating specific issues and sectors in isolation. In addition to reflecting the set general environmental principles, the MSFD goes well beyond the existing international framework. Establish an effective framework for coordination and cooperation at national level and ensure sufficient administrative capacity and sufficient financing. Coordination and cooperation at international level should also be addressed.

The analysis of the relevant Turkish legislation and its interplay with the general requirements of the MSFD revealed a series of legal gaps which will need to be filled when implementing the directive (Table 4).

Framework Directive of Marine Strategy contains many different headings and encompasses issues in the assignment field of many organizations including navigation, fishery, sea litters, and protection of ecosystems and biological diversity. Starting from all of these present studies as a result of the approached current status, an integrated national marine strategy is needed drawing a framework for our national requirements, liabilities assumed from regional marine contracts and sustainable management of marine areas.

In order to improve sea management further and support ecosystem based management, it has become a vital need to release a Document of National Sea Environment Strategy and Action Plan, covering duties and responsibilities of the concerned organizations and institutions and in this context, consisting of short/medium/long term objectives and measures. 
Table 4. Gaps between the institutional requirements of the MSFD and the relevant Turkish institutional system

1. The basic requirement for defining the geographical scope, the phrase "marine waters", is not defined in Turkish legislation.

2. The key phrase of the overall objective of the MSFD, i.e. "good environmental status", is not defined in Turkish legislation. Furthermore, there is no legislation specifying the eleven qualitative MSFD descriptors which describe what the environment will look like when GES has been achieved.

3. Key in the answer to this question is that there is no legal requirement in Turkish legislation to develop marine strategies which consist of five distinct and interlinked phases/elements which must be reviewed every six years. In addition, Turkish legislation does not require the application of an ecosystem based approach to environmental management.

4. The analysis of the Turkish legislation relevant for implementing the detailed requirements for the five distinct and interlinked phases of the implementation of the MSFD and for the eleven qualitative descriptors revealed a rather diverse picture with sometimes contradictory environmental legislation in force.

Table 5. Important steps to consider for the implementation of the Marine Strategy Framework Directive

1 Developing recommendations for the transposition of the MSFD into national law.

2 Promoting the preparation of draft legislation for the development of a national monitoring program under MSFD.

3 Organising awareness raising activities for general population, enhancing school education programs to include marine environmental issues as a regular curriculum, encouraging NGOs to undertake further campaigns on marine ecosystem protection, using marine litter problem as an examplary topic that is easy to understand by general population, organizing clean-up activities in the coastal area and in river basins, supporting fishing for litter, and art works related to marine environment protection awareness raising.

4 Ensure the active involvement of the general public in the establishment, implementation and updating of marine strategies for Turkish waters by arranging a public consultation prior to the adoption of marine strategies for Turkish waters.

5 Establish an effective framework for coordination and cooperation at national level and ensure sufficient administrative capacity and sufficient financing. Coordination and cooperation at international level should also be addressed.

6 The MoEU should be designated as competent authority for the development, review and implementation of marine strategies under the MSFD as well as for the coordination of this activity at national and international level.

7 With a strong link to the political level, an MSFD Coordination Committee should be established with representatives at the highest possible level of all ministries involved. The Coordination Committee should take decisions by consensus. The MoEU should act as chair of the Committee.

8 Coordinate development of a conceptual approach to aggregation of information by descriptors, integrating assessment results across scientific indicators and the GES Decision criteria for use by Member States and Regional Sea Conventions to achieve consistent and regionally coherent future assessments.

9 Turkey is party to the Bucharest Convention for the protection of the Black Sea as well as to the Barcelona Convention (UNEP/MAP) for the protection of the Mediterranean and to a series of protocols adopted under these conventions. it is necessary to ensure coordination with regional seas conventions.

In this context, it is critical that a coordination commission of sea environment is formed and a legislation study is conducted to establish a basis for the commission's operation so that studies carried out on prevention of marine pollution by international organizations will be monitored efficiently and effectively and these studies will be managed and directed by the concerned institutions and organizations in coordination.

In this context; in order to adopt the principle of ecosystem-based management, which is the main pillar of the MSFD for the Turkish marine areas (including territorial waters), in the context of defining the current administrative/legal/institutional situation for the implementation of the Marine Strategy Framework Directive (MSFD) and determining the gaps and developing the suggestions, the following actions will be important steps to consider (Table 5).

The requirements for the legislation implementing the MSFD in Turkey can be structured to answer three main questions, where, what and how, i.e.:

- Where is MSFD applicable? - geographical scope;

- What needs to be attained?- good environmental status of marine waters;

- $\quad$ How can this be attained? - Requirements for the development of marine strategies; requirements for public consultation and information; requirements regarding cooperation and coordination. 
The analysis of the relevant Turkish legislation and its interplay with the general requirements of the MSFD revealed a series of legal gaps that will need to be filled when implementing the directive. Gaps can be summarised as follows:

Where: the basic requirement for defining the geographical scope, the phrase "marine waters", is not defined in Turkish legislation;

What: the key phrase of the overall objective of the MSFD, i.e. "good environmental status", is not defined in Turkish legislation. Furthermore, there is no legislation specifying the eleven qualitative MSFD descriptors which describe what the environment will look like when GES has been achieved.

How: key in the answer to this question is that there is no legal requirement in Turkish legislation to develop marine strategies which consist of five distinct and interlinked phases/elements which must be reviewed every six years. In addition, Turkish legislation does not require the application of an ecosystem based approach to environmental management.

The analysis of the Turkish legislation relevant for implementing the detailed requirements for the five distinct and interlinked phases of the implementation of the MSFD and for the eleven qualitative descriptors revealed a rather diverse picture with sometimes contradictory environmental legislation in force. In summary, this leads to three possible approaches that could be followed by Turkey as given in Table 6 .

All three approaches would require an adaptation of existing Turkish legislation either by repealing inconsistent legislation or by amending existing legislation. Turkey should start its work with a detailed analysis of the three options for transposing the MSFD.

Table 6. Possible approaches which could be followed by Turkey

$\begin{array}{ll}1 & \text { Transposing the MSFD by amending existing legislation } \\ 2 & \text { Transposing the MSFD by establishing separate pieces of legislation for specific MSFD elements } \\ 3 & \text { Transposing the MSFD as a whole into a separate piece of legislation }\end{array}$

\section{Discussion and Conclusion}

Lack or inadequacy of legislation that might be responsible for occurrence of environmental problems or unsettlement of these problems, in other words, responsible for the "outcomes" related to environment is out of question in Turkey. In Turkey, there is a quite large and comprehensive environmental legislation in place and each day new regulations are incorporated into it within the scope of adjustment to the EU legislation. However, the existing institutional and legal infrastructure is currently not able to bring together all the components or produce joint assessments for our seas. In this context, one of the most important topics is to increase the cooperation between institutions and to ensure a competent and effective coordination.

As a result of the current situation, starting from all these existing studies; There is a need for an integrated national maritime strategy that takes into account our national needs, our Regional marine convention obligations, and the MSFD, which draws a framework for the policies regarding the sustainable management of marine areas within the framework of the legislation harmonization studies carried out in accordance with the EU candidate country status. In the framework of an integrated national marine strategy, if our country follows the latest developments in regional marine convention, marine monitoring programs will also become more multicomponent, the need to produce holistic information will increase and it will have to design more complex programs. With these programs, the ultimate goal will be the determination and follow-up of Good Environmental
Status, status assessments to be made in 6-year cycles, and control of Good Environmental Status targets.

Due to the increasing legal and actual requirements explained above, there is a need for a "National Marine Environment Protection Strategy" and "National Marine Environment Protection Strategy Action Plan" that will contribute to the coordination of the studies. As a result, the Marine Research Strategy will provide a workable basis for establishing national policies and relevant legislation for good environmental status. One of the key priority elements for a successful implementation of the MSFD is the establishment of an effective framework for coordination and cooperation among national, regional and local authorities.

\section{Acknowledgements}

This manuscript has resulted from the MARinTURK (Marine Strategy Framework Directive Capacity Building Project in Turkey) project funded by the European Union (Project Identification No: EuropeAid/135965/IH/SER/TR Contract No: TR2011/0327.21.06.01), ttp://marinturkproject.com. Author would like to thank Ministry of Environment and Urbanization for their valuable comments and inputs that helped to increase the quality of the paper. Finally, special thanks to Prof. Dr. Ahmet KIDEYS from METU, who gently reviewed and made constructive comments in the article.

\section{References}

Akyüz, E. (2021). The Development of Environmental Human Rights. International Journal of Environment 
and Geoinformatics, 8(2), 218-225, doi.10. 30897/ijegeo.839725

Atkins, J.P., Burdon, D., Elliott, M., Gregory, A.J. (2011). Management of the marine environment: integrating ecosystem services and societal benefits with the DPSIR framework in a systems approach. Marine Pollution Bulletin, 62(2), 215-226.

Avaz, G. (2017). Updating the National Action Plan for Protecting Marine Environment Against Land Based Sources Project. CTUE 5168703, Report No. CTUE. 13.155(Final Report).December 2017, GebzeKocaeli.

Barnes R., Metcalf D. (2010). Current Legal Developments - The European Union: The Marine Strategy Framework Directive. International Journal of Marine and Coastal Law, 25 (1), 81-91.

Başak Dessane, E. (2017): Benefits and Costs of Environmental and Natural Resources- Examples from Turkey, Workshop on Economic and Social Analysis and Programmes of Measures in accordance with the MSFD: 10-14 July 2017, Bolu.

Beken, C. (2017): How marine monitoring is divided between different institutions, Workshop on Environmental Targets and Monitoring requirements of the MSFD: 22-26 May 2017, Bodrum, Muğla.

Beken, C., Aydöner, C., Ediger, D., Hüsrevoğlu, S., Mantıkçı, M., Aydöner, C., Olgun, A., Sözer, B., Tan, İ., Karakoç, F.,Tolun,L., Tutak, B., Tüfekçi, H., Tüfekçi, V.( 2014). Marine and Coastal Waters Quality Determination and Classification Project (DeKoS Project). CTUE 5118703, Report No. CTUE.13.155 (Final Report), February 2014, GebzeKocaeli.

Beken, C., Kıdeyş, A., Beşiktepe,S., Yüksek, A. (2013). Good Environmental Status of Definition and Goals in Turkey Marines. -Coastal Management in Turkey: Recent Developments in National Workshop, 17 May 2013, Marmaris, Muğla.

Bellas,J.(2014). The implementation of the Marine Strategy Framework Directive: Shortcomings and limitations from the Spanish point of view. Marine Policy, 50(1), 10-17.

Berg, T., Fürhaupter, K., Teixeria, H., Uusitalo,L., Zampoukas,N. (2015). The Marine Strategy Framework Directive and the ecosystem-based approach - pitfalls and solutions, Marine Pollution Bulletin, $\quad 96(1-2), \quad$ 18-28. DOI: 10.1016/j.marpolbul.2015.04.050.

Bertrama, C., Dworak,T., Görlitz, S., Interwies, E., Rehdanz, K. (2014). Cost-benefit analysis in the context of the EU Marine Strategy Framework Directive: The case of Germany. Marine Policy, 43,307-312.

Borja, A., Elliott, M., Carstensen, J., Heiskanen,A.S., Bund,W. ( 2010). Marine management - Towards an integrated implementation of the European Marine Strategy Framework and the Water Framework Directives. Marine Pollution Bulletin, 60(12), 21752186.

Burak, S., Doğan, E., Gazioğlu, C. (2004). Impact of urbanization and tourism on coastal environment, Ocean Coast Manag., 47, 15-527, doi.10.1016/j.ocecoaman.2004.07.007
Casazza, G., Lopez Y Royo, C., Dalu, M., S,Accomand F., Spada E., Silvestri C. (2007). Recent policies tools for ecological evaluation of Mediterranean Sea. Proceedings of the Eight International Conference on the Mediterranean Coastal Environment, Alexandria, Egypt.

Çetin, O. (2021). Relationship with Marine Environmental Consciousness and Maritime Culture in Turkey. International Journal of Environment and Geoinformatics, 8(3), 245-255, doi.10.30897 /ijegeo.862055

Convention On Biological Diversity (2000). Convention On Biological Diversity United Nations. Retrieved August 3, 2017 from Online At: Www.Cbdint / Doc / Legal / Cbd-Tr.Pdf.

Craglia, M., Bigagli, M. \& Smith R.S. (2010). SEISBASIS Analysis of Monitoring Requirements of the Environmental Acquis: Water Protection and Management. Administrative Arrangement between DG- Environment and Joint Research CentreInstitute for Environment and Sustainability.

Criese, A., Kaberi, H., Ruiz,J., Zatsepin, A., Arashkevich,E., Giani, M., Karageorgis,A.P., Prieto,L., Pantazi, M., Gonzales-Fernandes,D., Ribera,M., Tornero,V.,Vassilopoulou,V., Durrieu de Madron,X., Guieu,C., Puig,P., Zenetos,A., Andral, B., Papathanassiou,E. (2015). MSFD complementary approach for the assessment of pressures, knowledge and data gaps in Southern European Seas: The PERSEUS experience. Marine Pollution Bulletin, 95(1), 28-39. doi.10.1016/j.marpolbul.2015.03.024

Elge, M. (2017). Turkish National Marine Research Strategy and The Office of Navigation, Hydrography and Oceanography, Workshop on Turkey's Legal and Institutional Framework in Relation to the Marine Strategy Framework Directive, 23-27 January 2017, İzmir.

European Commission [EC] (2008). European Commission. Directive 2008/56/EC of the European Parliament and of the Council of 17 June 2008, establishing a framework for community action in the field of marine environmental policy (Marine Strategy Framework Directive). Official J. Eur. Union, L164: $19-40$.

European Commission [EC] (1992). Council Directive 92/43/EEC of 21 May 1992 on the conservation of natural habitats and of wild fauna and flora.

European Commission [EC] (2000). Directive 2000/60/EC of the European parliament and of the council, of 23 October 2000, establishing a framework for Community action in the field of water policy. Official Journal of the European Communities, G.U.C.E. 22/12/2000, L 327.

European Commission [EC] (2009). Directive 2009/147/EC of the European Parliament and of the Council of 30 November 2009 on the conservation of wild birds.

European Commission [EC] (2010). Commission Decision 2010/477/EU of 1 September 2010 on criteria and methodological standards on good environmental status of marine waters. Brussels: Official J. Eur. Union, L232, 14- 24. 
European Commission [EC] (2011). Common Understanding of (Initial) Assessment, Determination of Good Environmental Status (GES) and Establishment of Environmental Targets (Art. 8, 9 \& 10 MSFD). EuropeanCommission, Brussels. In CIRCABC - EC - Marine Strategy - Library: ADocuments: A2-Guidance Documents, GD n. 01.

European Commission [EC] (2014). (COM(2014) 97 final). Report from the Commission to the European Parliament: The first phase of the Marine Strategy Framework Directive (2008/56/EC), The European Commission's assessment and guidance.

European Commission [EC] (2017). Commission Decision (EU) 2017/848 of 17 May 2017 laying down criteria and methodological standards on good environmental status of marine waters and specifications and standardised methods for monitoring and assessment, and repealing Decision 2010/477/EU.

Gazioğlu, C. (2018). Biodiversity, Coastal Protection, Promotion and Applicability Investigation of the Ocean Health Index for Turkish Seas. International Journal of Environment and Geoinformatics, 5(3), 353-367, doi.10.30897/ijegeo.484067.

Giakoumis,T., Voulvoulis, N. (2019). Water Framework Directive programmes of measures: Lessons from the 1 st planning cycle of a catchment in England. Science of The Total Environment, 668, 903-916. doi. 10.1016/j.scitotenv.2019.01.405

Hoeya,G.V.,Borja,A.,Birchenough,S., Mortensen,L.B., Degraer,S., Fleischere,D., Kerckhof,F., Magni,P., Muxika,I.,Reiss,H., Schröder,A., Zettler,M.L.(2010). The use of benthic indicators in Europe: From the Water Framework Directive to the Marine Strategy Framework Directive. Marine Pollution Bulletin, 60(12), 2187-2196. doi.10.1016/j.marpolbul 2010.09.015

Holzwarth, F., Leujak, W., Arle, J., Claussen, U. (2009). Implementing the Marine Strategy Framework Directive (MSFD) in Germany - Moving towards an assessment framework for "good environmental status". Conference: Progress in Marine Conservation in Europe 2009. Pages, 199-210. See discussions, stats, and author profiles for this publication

Hoof, L.V., Hendriksen, A., Bloomfield, H.J. ( 2014). Sometimes you cannot make it on your own; drivers and scenarios for regional cooperation in implementing the EU Marine Strategy Framework Directive. Marine Policy, 50, 39-346. doi.10.1016/j.marpol.2014.03.031

Kocaman, I. (2017). The Results Obtained with the Economic Analysis of the Use of Sea Water in Turkey, Workshop on Economic and Social Analysis and Programmes of Measures in accordance with the MSFD, 10 - 14 July 2017, Bolu

Leeuwen, J.V., Raakjaer, J., Hoof, L.V., Tatenhove, J.V., Long,R., Ounanian,K. (2014). Implementing the Marine Strategy Framework Directive: A policy perspective on regulatory, institutional and stakeholder impediments to effective implementation. Marine Policy, 50, 325-330. doi.10.1016/j.marpol.2014.03.004
Long, R. (2011). The Marine Strategy Framework Directive: A New European Approach to the Regulation of the Marine Environment, Marine Natural Resources and Marine Ecological Services. Journal of Energy \& Natural Resources Law, 29(1), 1-44. doi.10.1080/02646811.2011.1143525

Lyon, B.P.,Thain, J.E., Stentiford, G.D., Hylland, K., Davies, I.M., Vethaak, A.D. ( 2010). Using biological effects tools to define Good Environmental Status under the European Union Marine Strategy Framework Directive. Marine Pollution Bulletin, 60, 1647-165. DOI: 10.1016/j.marpolbul.2010.06.005

Marcus, T., Schlake S., Maier N. (2011). Legal implementation of integrated ocean policies: the EU's Marine Strategy Framework Directive. International Journal of Marine and Coastal Law, 26, 59-90. doi:10.1163/157180811X541404

Marine Monitoring Guidelines [MMG] (2017). Deniz İzleme Kılavuzları

MARinTURK (2017). TR2011/0327.21.06.01 numbered "Marine Strategy Framework Directive Capacity Building Project in Turkey"

Millennium Ecosystem Assessment [MEA] (2005). Ecosystems and Human Well-being: Synthesis. Washington (DC) Island Press.

National Marine Research Program [NMRP] (2017). Gemi İstatistikleri

Oral, N. (2017). The EU Marine Strategy Framework Directive on the implementation of existing legislation in Turkey and corporate due diligence and gaps. Workshop on Turkey's Legal and Institutional Framework in Relation to the Marine Strategy Framework Directive, İzmir.

Savun-Hekimoğlu, B., Erbay, B., Burak, Z.S., Gazioğlu, C. (2021). A Comparative MCDM Analysis of Potential Short-Term Measures for Dealing with Mucilage Problem in the Sea of Marmara, International Journal of Environment and Geoinformatics, 8(4), 572-580, doi.10. 30897/ijegeo.1026107

Savun-Hekimoğlu, B., Gazioğlu, C. (2021). Mucilage Problem in the Semi-Enclosed Seas : Recent Outbreak in the Sea of Marmara. International Journal of Environment and Geoinformatics (IJEGEO), 8(4). doi.10.30897/ijegeo.955739

Semeniene, D. (2017). Requirements of Economic and Social Analysis in accordance with the MSFD and Approaches Recommended. Workshop on Economic and Social Analysis and Programmes of Measures in accordance with the MSFD, 10-14 July 2017, Bolu.

Simav, Ö., Şeker, D.Z., Tanık, A. Gazioğlu, C. (2015). Determining the endangered fields of Turkish coasts with coastal vulnerability index. Journal of Map, 153: 1- 8

Walmsley, S.F., Weiss, A., Claussen, U., Connor, D. (2017). Guidance on assessments under Article 8 of the Marine Strategy Framework Directive, Integration of evaluation results. Report No. 2733 prepared by ABPmer for the European Commission Directorate General for Environment February 2017.

Zampoukas N, Piha H, Bigagli E, Hoepffner N, Hanke G, Cardoso AC. ( 2012). Monitoring for the Marine 
Strategy Framework Directive: Requirements and options. JRC Scientific and Technical Reports.

Zampoukas N, Piha H, Bigagli E, Hoepffner N, Hanke G, Cardoso AC. (2013). Marine monitoring in the European Union: How to fulfill the requirements for the marine strategy framework directive in an efficient and integrated way. Marine Policy, 39, 349-351.

Zampoukas, N., Palialexis, A., Duffek, A., Graveland, J., Giorgi, G., Hagebro, C., Hanke, G., Korpinen, S., Tasker, M., Tornero , V., Abaza, V., Battaglia, P., Caparis, M., Dekeling, R., Frias Vega, M., Haarich, M., Katsanevakis, S., Klein, H., Krzyminski, W., Laamanen, M., Le Gac, J.C., Leppanen, J.M., Lips, U., Maes, T., Magaletti, E., Malcolm, S., Marques, J.M., Mihail, O., Moxon, R. (2014). JRC Scientific and Policy Reports Technical guidance on monitoring for the Marine Strategy Framework Directive. EC-, Report EUR 26499 EN. 